\title{
Emotional Maturity across Gender and Level of Education
}

\author{
Mukhtar Ahmad Wani 1 , Prof. Aejaz Masih 2
}

\section{ABSTRACT:}

The purpose of the present study is to identify the level of emotional maturity among university students and to find the significant differences in emotional maturity across gender and their level of education. To achieve the stipulated objectives descriptive method of research was followed. The sample for the present investigation was randomly drawn from different department of Jamia Millia Islamia New Delhi. A total sample of 100(50 male \& 50 female) including Post Graduates and Research Scholars were selected. The data was collected by administering the Emotional Maturity Scale developed by Prof. Yeshver Singh \& Prof. Mahesh Bhargave (1990). The data was then analyzed through Mean, sd and t-test for the comparison of mean scores between groups with the help of SPSS 21. The findings of the study revealed that majority of the post graduate students and research scholars of the university are emotionally unstable. The findings also showed that male students are emotionally immature than females on personality disintegration dimension of emotional maturity. Significant difference was also found between post graduates and research scholars on personality disintegration dimension of emotional maturity. On other dimensions of emotional maturity no difference was found between males and females and post graduates and research scholars University students must be taught to identify their level of emotional maturity, as they are at the highest seat of learning.

Keywords: Emotional Maturity, Gender, Post Graduate Students, Research Scholars,

\section{INTRODUCTION:}

"Emotions shape the landscape of our mental and social lives. Like the 'geographical upheavals' a traveler might discover in a landscape where recently only a flat plane could be seen, they mark our lives as uneven, uncertain, and prone to reversal".

(Nussbaum 2001)

Life is becoming very fast with the advancement of science and technology. The $21^{\text {st }}$ century is an era of technological revolution. Due to the technology, the environment is changing as never before. Youth as well as adults of today are well and easily exposed to vast, unlimited and most importantly censored information and are subject to high pressure because of ever increasing competition and expectations from their family and peers.

\footnotetext{
${ }^{1}$ Ph.D Research Scholar, Department of Educational Studies, Jamia Millia Islamia, New Delhi-110025

${ }^{2}$ Professor, Department of Educational Studies, Jamia Millia Islamia, New Delhi-110025

(C) 2015, M Wani, A Masih; licensee IJIP. This is an Open Access Research distributed under the terms of the Creative Commons Attribution License (http://creativecommons.org/licenses/by/2.0), which permits unrestricted use, distribution, and reproduction in any Medium, provided the original work is properly cited.
} 
Under this dynamic environment the youth as well as adults are finding it difficult to adjust them and even sometimes succumb to the environmental pressure. Though man has conquered time and space to a great extent by the present level of scientific advancement, yet there is great threat to his existence. The Indian society is becoming increasingly materialistic. The present generation is moving ahead to achieve their material gains by every means. They find it hard to bridge the gap between their head and heart. This puts them always in conflicting situations. For the personal happiness it is very important that you must be aware about yourself and must be able to tolerate a delay in the satisfaction of your needs. For this purpose you have to choose maturity, to behave in a consciously designed manner. Maturity is the ability to respond to the environment in an appropriate manner. This response is generally learned rather than instinctive. Maturity also encompasses being aware of the correct time and place to behave and knowing when to act, according to the circumstances and the culture of the society one lives in (David Wechsler 1950). According to Finley (1996), "Maturity is the capacity of mind to endure an ability of an individual to respond to uncertainty, circumstances or environment in an appropriate manner".

As we discussed above that youths and adults are facing a lot of difficulties and pressures from the competitive materialistic world, so they are vulnerable to different psychological problems. Therefore, here the study of maturity in emotional aspect of personality is challenging our attention. Menninger (1999), Emotional maturity includes the ability to deal constructively with reality. Dosanjh (1960) "Emotional maturity means balanced personality. It means ability to govern disturbing emotion, show steadiness and endurance under pressure and be tolerant and free from neurotic tendency". Prof Y. Singh (1990) "Emotional maturity is not only the effective determinant of personality pattern but also helps to control the growth of an adolescent's development. A person who is able to keep his emotions under control, to brook delay and to suffer without self-pity might still be emotionally stunned". So emotionally mature person will have more satisfaction in life; he will be satisfied with what he is and have a balance between his head and heart.

Consistent studies have been conducted on the emotional maturity of the adolescents and adults. Like K. Subbarayan \& G. Visanathan (2011) concluded that the sex, community and family type did not play any role in emotional maturity of college students. It also revealed that majority of college students are extremely unstable. Manoharan, R. John Louis and I. Christie Doss (2007) concluded that emotional maturity of P.G. students is influenced by sex, class and group. The level of emotional maturity of female students is higher than that of the male students. Sheema Aleem (2005) reported that female students are less emotionally stable as compared to male students. Lakshmi, S. and Krishnamurthy, S. (2011) reported that the majority of Higher Secondary Students in Coimbatore District are in Emotionally Unstable condition. Deand, G., \& Bruton, B.T. (1989) concluded that Emotional maturity is related to better marital adjustment. Sunil Kumar (2014) discloses that a significant correlation exists between emotional maturity and family relationship. From the review of different sources it was found that no comprehensive study was conducted on the university students and the investigator makes an effort to identify the level of emotional maturity in university students, keeping in view their level of education. 


\section{Justification of the Study:}

As has been described by Edward E. Morler, "Children and adolescents are driven by genes and hormones. However, beyond adolescence, an individual has to choose maturity. While emotional intelligence can be learned, emotional maturity is a choice. If it is not consciously made, the individual will not move beyond the emotional immaturity of an adolescent despite any and all trappings of material success". Emotional maturity is not something that necessarily grows with chronological age; we don't get more emotionally mature when we get older. Some adults are very emotionally immature and some have never matured. Hence they all find it difficult to adjust themselves with the changing environment of this scientific age. Therefore it is the dire need of the hour that our adolescents and adults should have proper emotional development to rightly channelize their emotions. Emotional maturity becomes very important in the behaviour of the individuals, as students are the pillars of the nation and future generations, so their level of emotional maturity becomes very vital. This study is of significant value for students, families, teachers and administrators, as they can be made aware about the level of emotional maturity of their grown up youths. It will be quite helpful for post graduates and research scholars, who are at the highest seats of learning in universities to pay a good time of attention to their emotional maturity and make successful adjustments, whatever the situations are. Study will also try to make adolescents and adults to realize that becoming emotionally mature means becoming aware of their choices and their impacts. Being a post graduate or a researcher doesn't necessarily make a person capable of handling the situations. Therefore need was felt to study the level of emotional maturity of university students across gender and their level of education.

\section{OBJECTIVES:}

The following objectives have been framed for the present investigation:

1. To study the level of Emotional Maturity among the university students.

2. To find the significant differences in Emotional Maturity among university students across gender.

3. To find the significant differences in Emotional Maturity in Post graduate students and Research Scholars of the University.

\section{HYPOTHESIS:}

1. There is no significant difference between male and female university students in Emotional Maturity.

2. There is no significant difference between Post graduate students and Research Scholars in Emotional Maturity. 


\section{METHOD:}

The present study was carried out by employing the descriptive method of research. Generally, in a descriptive research the researcher is concerned with why observed distribution exists but more particularly with what the distribution is. The descriptive survey used a number of data collection methods to compensate for inadequacies of each individual method. It was selected because it was intended to gather information from section respondents and to gather data at a particular point in time, and use it to describe the nature of existing conditions (Cohen, Manion \& Morrison, 2007).

\section{Sample:}

The participants for the present investigation were randomly drawn from different Departments of Jamia Millia Islamia (A Central University) New Delhi. A total of 100 participants (50 male \& 50 female) including Post Graduates and Research Scholars were selected.

\section{Tool:}

Emotional Maturity Scale developed by Prof. Yeshver Singh \& Prof. Mahesh Bhargave (1990) was used to gather the relevant information from the selected sample.

\section{PROCEDURE:}

Before the administration of the test, the nature of the data and the purpose of research were discussed with the sample population. Then the test was administered. After the administration of the test to the selected samples the scoring was done strictly in accordance with the directions in the test manual. The collected data was statistically analyzed through mean, s.d and t-test for testing the significance of mean differences between the groups with the help of SPSS 21 Software. The details of analysis and interpretation are given below: 
Objective 1: To study the level of emotional maturity among the university students. Graphical representation of level of emotional maturity among university students.

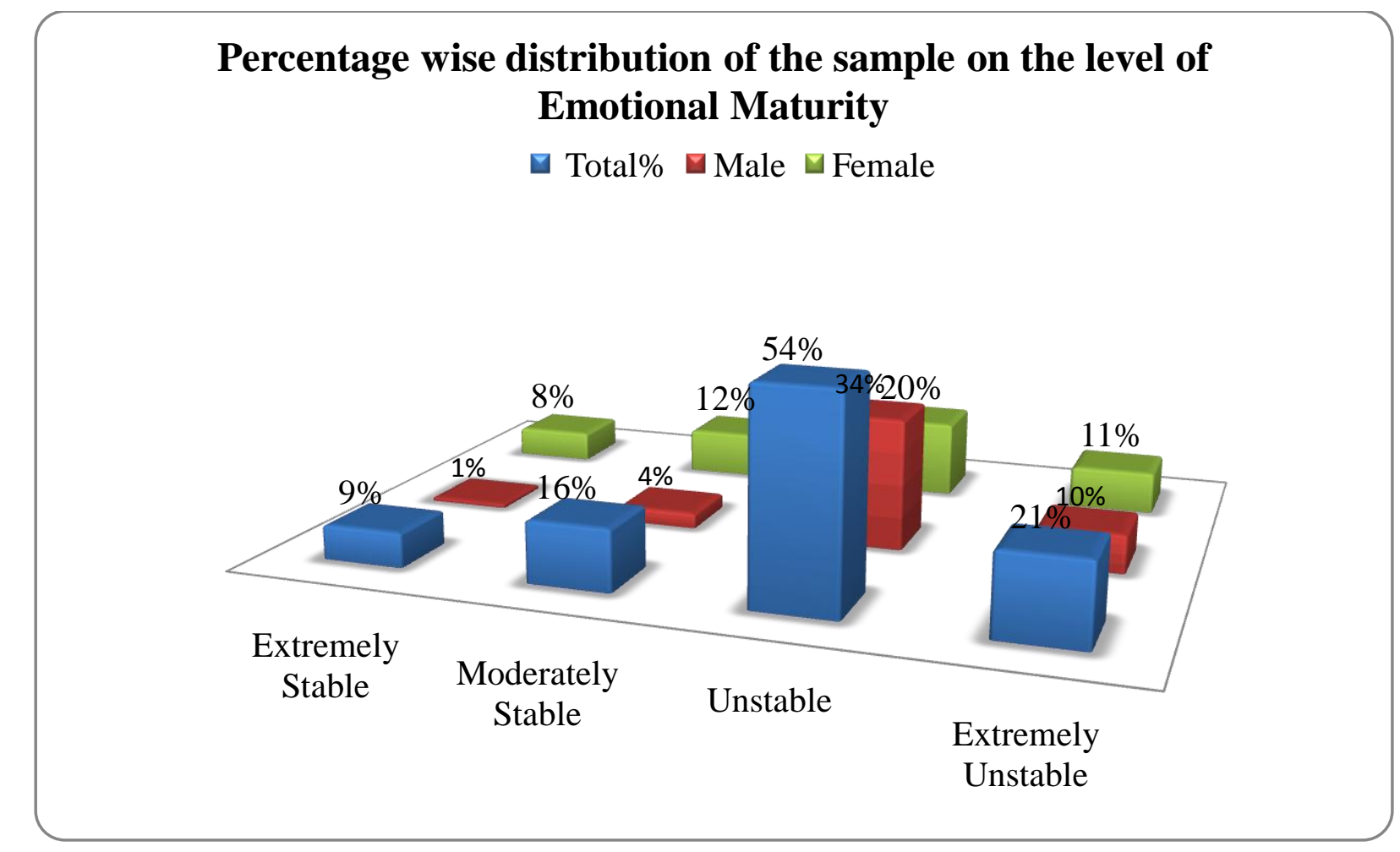

From the perusal of the above graphical representation of the data only $9 \%$ university students are extremely stable, $16 \%$ are moderately stable, $54 \%$ are unstable and $21 \%$ of the university students are extremely unstable. The large segment of the university students is emotionally unstable and also a reasonable section of the university students are extremely unstable. The reasons for this unstable emotional maturity may be due to the present competitive environment and the very busy and fast life going ahead, where university students didn't give any preference to their emotional aspect of their development. But for happy, successful personal and professional life human beings has to choose emotional maturity as a conscious choice.

\section{Objective 2: To find the significant differences in Emotional Maturity across gender.} Hypothesis: There is no significant difference between male and female university students in Emotional Maturity.

In order to measure the significance of difference between male and female university students, the ' $t$ ' value was calculated. The data for the same is presented: 
Table 1: Mean score difference between male and female university students in emotional maturity on various dimensions.

\begin{tabular}{|c|c|c|c|c|c|c|}
\hline \multirow{2}{*}{ Dimensions } & \multicolumn{2}{|c|}{ Male } & \multicolumn{2}{c|}{ Female } & \multirow{2}{*}{ t Value } & \multirow{2}{*}{ Sig. } \\
\cline { 2 - 6 } & Mean & S.D & Mean & S.D & & $.626^{* *}$ \\
\hline $\begin{array}{c}\text { Emotional } \\
\text { Unstability }\end{array}$ & 20.46 & 3.38 & 20.04 & 5.04 & $\mathbf{. 4 8 9}$ & $.471^{* *}$ \\
\hline $\begin{array}{c}\text { Emotional } \\
\text { Regression }\end{array}$ & 21.24 & 4.82 & 20.54 & 4.84 & $\mathbf{. 7 2 4}$ & $.687^{* *}$ \\
\hline $\begin{array}{c}\text { Social } \\
\text { Maladjustment }\end{array}$ & 20.36 & 4.57 & 20.76 & 5.29 & $\mathbf{- . 4 0 4}$ & $.009^{*}$ \\
\hline $\begin{array}{c}\text { Personality } \\
\text { Disintegration }\end{array}$ & 21.60 & 4.29 & 18.80 & 6.06 & $\mathbf{2 . 6 6}$ & $.062^{* *}$ \\
\hline $\begin{array}{c}\text { Lack of } \\
\text { Independence }\end{array}$ & 15.12 & 3.63 & 13.86 & 3.01 & $\mathbf{1 . 8 8}$ & \\
\hline
\end{tabular}

*Significant

** Insignificant

From the perusal of the above table 1 , it is revealed that the t-value between male and female university students on personality disintegration dimension of emotional maturity is 2.66 which is statistically significant with .009 significance value. However on dimensions of emotional stability, emotional regression, social maladjustment and lack of independence dimensions of emotional maturity t-value comes to be $.489, .724,-.404$ and 1.88 respectively which are statistically insignificant. Therefore, the null hypothesis (1) formulated earlier i.e. "There is no significant difference between male and female university students in emotional maturity" is partially accepted. This is also supported by Manoharan, et al (2007). 
Objective 3: To find the significant differences in Emotional Maturity in Post graduate students and Research Scholars of the University.

Hypothesis: There is no significant difference between Post graduate students and Research Scholars in Emotional Maturity.

In order to measure the significance of difference between post graduate and research scholars of the university, the 't' value was calculated. The data for the same is presented below in the table.

Table 2: Mean score difference between Post graduate students and Research Scholars on various dimensions of Emotional Maturity.

\begin{tabular}{|l|c|c|c|c|c|c|}
\hline \multirow{2}{*}{ Variables } & \multicolumn{2}{|c|}{$\begin{array}{c}\text { Post Graduate } \\
\text { Students }\end{array}$} & \multicolumn{2}{c|}{ Research Scholars } & \multirow{2}{*}{ t Value } & \multirow{2}{*}{ Sig. } \\
\cline { 2 - 7 } & Mean & S.D & Mean & S.D & & $.206^{* * *}$ \\
\hline $\begin{array}{l}\text { Emotional } \\
\text { Unstability }\end{array}$ & 20.80 & 4.86 & 19.56 & 5.03 & $\mathbf{1 . 2 7}$ & $.901^{* * *}$ \\
\hline $\begin{array}{l}\text { Emotional } \\
\text { Regression }\end{array}$ & 20.46 & 5.01 & 20.34 & 4.56 & $\mathbf{. 1 2 5}$ & $.482^{* * *}$ \\
\hline $\begin{array}{l}\text { Social } \\
\text { Maladjustment }\end{array}$ & 19.28 & 5.05 & 20.04 & 5.68 & $\mathbf{- . 7 0}$ & $.033^{*}$ \\
\hline $\begin{array}{l}\text { Personality } \\
\text { Disintegration }\end{array}$ & 20.84 & 4.18 & 18.92 & 4.68 & $\mathbf{2 . 1 6}$ & $.423^{* *}$ \\
\hline $\begin{array}{l}\text { Lack of } \\
\text { Independence }\end{array}$ & 14.80 & 3.60 & 14.16 & 3.08 & $\mathbf{. 8 0}$ & \\
\hline
\end{tabular}

Significant

*** Insignificant

From the perusal of the table 2, it is revealed that $\mathrm{t}$-value between post graduates and research scholars on personality disintegration dimension of emotional maturity is 2.16 , which is statistically significant with .033 significance value. However on emotional unstability, emotional regression, social maladjustment, and lack of independence dimensions of emotional maturity t-value comes out to be $1.27, .125,-.70$, and .80 respectively, which are statistically insignificant. Therefore, the null hypothesis (2) formulated earlier i.e. "There is no significant 


\section{difference between Post graduate students and Research Scholars in Emotional Maturity"}

is partially accepted.

\section{Findings and Discussion:}

The findings of the study revealed that only $9 \%$ university students are extremely stable, $16 \%$ are moderately stable, $54 \%$ are unstable and $21 \%$ of the university students are extremely unstable. The large segment of the university students is emotionally unstable and also a reasonable section of the university students are extremely unstable. This is a matter of concern for the adults, who are supposed to take different roles in the society after this higher stage of education. The reasons for this unstable emotional maturity may be many like competition, employment, increasing stress due to changing environment etc. Due to these circumstances the university students find it hard to pay attention towards emotional aspect of their development.

The findings also revealed that there is significant difference between male and female, post graduate university students and research scholars on personality disintegration dimension of emotional maturity. Study showed that males and total post graduate students are emotionally immature than females and research scholars respectively on personality disintegration dimension of emotional maturity. These are against the results of Gakher (2003), Meenakshi \& Saurashtra (2003) and Kour M.(2001), which found there is no significant difference between males and females on emotional maturity. The differences in the personality disintegration dimension of emotional maturity males and females may be due to the fact that males become anxious very soon. Their feeling of insecurity, lack of ability to adjust makes them emotionally immature. They may get annoyed easily by things and people, showing marked dissatisfaction. They get frustrated easily as compared to females. Whereas females face the society and strenuous situations rather than running away from it. They have the capacity to withstand delay in satisfaction of needs, ability to tolerate a reasonable amount of frustration, belief in long term planning and are capable of delaying or revising their expectations in terms of demands of the situations. This makes females at emotionally mature than males.

\section{CONCLUSION:}

The present study highlights the level of emotional maturity among university students across gender and level of education. It was found that majority of post graduates and research scholars of the university are emotionally unstable and also females are better emotionally then males. The university students must try to understand that what lies there which make them emotionally unstable? The level of education doesn't make them emotionally mature. Emotionally maturity is not something that grows with chronological age. Therefore they must decide to have emotionally maturity as a conscious choice and enjoy life in a happy and balanced way. Gender differences can be attributed to the variations in socialization process of both genders than to the inherent genetic character. Moreover, the difference is not so massive that it cannot be subdued. 
Therefore the adults must be provided opportunities to strengthen their emotions so that they can easily face the realities of life and make successful adjustments.

\section{EDUCATIONAL IMPLICATIONS:}

The present study may help the parents, teachers and administrators to have knowledge of the emotional development of their children and students and help them in building a well balanced personality. Emotional Development is one of the major aspects of human growth and development. Emotions like anger, fear, love etc. play a great role in the development of child's personality. Not only his physical growth and development is linked with his emotional makeup, but his intellectual, social, moral and aesthetic development are also controlled by his emotional behavior and experiences. The overall importance of emotional experiences in the life of a human being makes it quite essential to know about the emotions. Emotional development reaches its maximum in adulthood. During this stage, generally all individuals attain emotional maturity. The study will benefit the post graduates and research scholars to have a kind attention towards their emotional development and will make them aware about the importance of emotional maturity in the present fast changing global world.

\section{REFERENCES:}

1. Aleem, S. (2005, july). Emotional Stability among College Youth. Journal of Indian Academy of Applied Psychology, 31, 100-102.

2. Best, J. W., \& Kahn, J. V. (2010). Research in Education. New Delhi: PHI Learning Ltd.

3. Ferguson, G. A., \& Yashio, T. (1989). Statistical Analysis in Psychology and Education. New York: McGraw Hill Book Co.

4. Festinger, L., \& Katz, D. (1965). Research Methods in the Behavioural Sciences. New York \& New Delhi: Amerind Pub Co. Pvt Ltd \& Holt, Rinehart \& Winston New York, Indian Print.

5. Hangal, S, \& Aminabhavi, A. (2007).Self- Concept, Emotional Maturity and Achievement Motivation of the Adolescent Children of Employed Mothers and Homemakers. Journal of Indian Academy of Applied Psychology, 33(1), 103-110.

6. Hussain, D.(2010). A Study of Parenting Style, Emotional Maturity and Academic Achievement among adolescents. Unpublished Ph.D Thesis, Jamia Millia Islamia, New Delhi.

7. Garret, H. E. (1973). Statistics in Psychology and Education. New Delhi: Paragon International Publishers.

8. Kaur, M. (2001). A study of emotional maturity of adolescents in relation to intelligence, academic achievement and environmental catalysts. Ph.D Thesis, Punjab University, Chandigarh. 
9. Kaur, M. M. (2013, january). A Comparative study of Emotional Maturity of Senior Secondary School Students. International Indexed Referred Reseach Journal, 48-49.

10. Kerlinger, F. N. (1983). Foundations of Behavioural Research (2nd ed.). Delhi: Surjeet Pub. Molt, Rinchart \& Winston, Inc.

11. Kour, J., \& Arora, B. (2014). Coping styles among teachers trainees in relation to emotional maturity. IMPACT: International Journal of Research in Humanities, Arts and Literature, 2(4), 29-34.

12. Kumar, S. (2014). Emotional Maturity of Adolescent Students in Relation to Their Family. International Research Journal of Social Sciences, 6-8.

13. Kumar, T. V. (2012). A comparative study of emotional maturity among 8th to 12th class Students with the reference of internet surfing. International Indexed \& Refferred Research Journal, 4(37), 8-9.

14. Passer, M. M., \& Smith, R. E. (2009). Psychology: The Science of Mind and Behavior (4TH ed.). New York: McGraw-Hill Companies, Inc.

15. Strongman K.T. (2003). The psychology of emotion (5TH ed.). New York: John Wiley \& Sons Ltd.

16. Subbarayan, K., \& Visvanathan, G. (2011). A study on emotional maturity of college students. Recent Research in Science \& Technology, 3(1),153-155.

17. Wechsler, D. (1 March 1950). "Intellectual Development and Psychological Maturity". Child Development 21 (1): 45. doi:10.2307/1126418. JSTOR 1126418. 